\title{
EARLY WARNING SYSTEMS (E-WARS) DESIGN FOR EARLY DETECTION OF STROKE INCIDENCE
}

\author{
Feby Erawantini, Rinda Nurul Karimah \\ Health Program, State Polytechnic, Jember, Indonesia
}

\begin{abstract}
ABSTRAK
Stroke merupakan penyakit kegawatan neurologik yang jumlahnya terus meningkat dari tahun ke tahun serta menyebabkan kecacatan dan kematian di seluruh dunia. Penyakit stroke disebabkan oleh banyak faktor atau multikausal. Penelitian ini merupakan penelitian kualitatif yang dilaksanakan selama satu tahun dengan perancangan sistem menggunakan metode prototipe. Metode prototipe diawali dengan identifikasi kebutuhan, mapping, dan mekanisme inferensi. Identifikasi kebutuhan dilakukan berdasarkan hasil literatur review dan diskusi. Literatur review sebanyak 15 sumber yang terdiri dari artikel jurnal, buku dan prosiding dilakukan dengan langkah compare, contrast, criticize, synthesize dan summarize. Diskusi mengenai faktor risiko stroke dilaksanakan dengan para pakar, yaitu dokter ahli penyakit saraf. Hasil literatur review dan FGD menunjukkan identifikasi faktor penyebab stroke terdiri dari hipertensi, kadar glukosa dan kolesterol darah yang tinggi, penyakit jantung, faktor perilaku, misalnya perilaku merokok dan gemar minum alkohol, stres serta penyebab lain. Faktor resiko tersebut selanjutnya dilakukan mapping dalam bentuk prototipe aplikasi mobile melalui mekanisme inferensi. Luaran yang dihasilkan pada penelitian ini berupa prototipe early warning systems (E-WARS) untuk peringatan dini kejadian stroke. Hasil prototipe diharapkan dapat digunakan dalam operasional menjadi aplikasi mobile yang bermanfaat bagi masyarakat, khususnya untuk mengontrol secara mandiri dan personal faktor risiko terjadinya stroke. Hal tersebut ditujukan untuk skrining awal dan peringatan dini risiko terjadinya stroke. (FMI 2018;54:136-140)
\end{abstract}

Kata kunci: Stroke; peringatan dini; prototipe

\begin{abstract}
Stroke is a neurological disease whose occurrence increases from year to year and causes disability and death worldwide. Stroke is caused by many factors or multicausal. This was a qualitative study conducted for one year with system design using prototype method. The prototype method began with the identification of needs, mapping, and then inference mechanism. Identification of needs was based on the literature review and discussion. The literature review from 15 sources consisting of journal articles, books and proceedings was done by comparing, contrasting, criticizing, synthesizing and summarizing. Stroke risk factor discussion were carried out with neurologists. The results of the review and literature discussion found identification of factors that cause stroke, which consisted of hypertension, high blood glucose, cholesterol, heart disease, behavioral factors, such as smoking behavior and alcoholism, stress and other causes. The risk factors of stroke were then mapped in the form of mobile application prototype through inference mechanism. The output in this study was early warning systems (E-WARS) prototype for early detection of stroke occurrence. The prototype results were expected to be used in operations into mobile applications that were beneficial to the public, in particular for self-control and personal risk factors for stroke. It was intended for early screening and early detection of the risk of stroke. (FMI 2018;54:136-140)
\end{abstract}

Keywords: Stroke; early detection; prototype

Correspondence: Feby Erawantini, Health Program, State Polytechnic, Jember, Indonesia.

Email: feby_era@yahoo.co.id

\section{INTRODUCTION}

Stroke is one of neurological incidences whose morbidity is increasing every year. According to WHO (World Health Organization), 15 million people suffer from stroke every year in the world. Of these, 5 million died and other 5 million are permanently disabled. High blood pressure causes more than 12.7 million strokes worldwide. Deaths caused by stroke in Europe are about 650,000 every year. In developed countries, the incidence of stroke decreases, mostly due to the efforts to lower blood pressure and reduce smoking. However, the overall rate of stroke remains high due to aging population (WHO 2016). Stroke is also still a major cause of death and disability worldwide. Patients with stroke need long-term treatment. However, the cost of treatment is very high. This is coupled with the problem of decreased patient productivity (Fadjar 2014). The number of stroke patients in Indonesia in 2013 based on the diagnosis of health provider was estimated to be $1,236,825$ persons (7.0\%), whereas based on the diagnosis of health providers/symptoms was estimated to be $2,137,941$ persons (12.1\%o) (Pusdatin 2014). 
There are several ways to control blood pressure with routine control, blood pressure self-examination at home with electric blood pressure monitor, as well as maintaining the pattern of consumption, controlling stress and exercising regularly. However, along with the rapid development of technology, especially communication technology in Indonesia (Putri 2015), this is an opportunity to create mobile applications that has benefit to the community, especially to control hypertension and reduce the risk of stroke. Before a mobile application is created, firstly, it needs to design a prototype consisting of several stages that begin with the identification of the needs, development, design and utilization of the prototype on the operation.

\section{MATERIALS AND METHODS}

This study designed an E-Wars application for early detection of stroke occurrence using prototype method. The research flow is presented in Fig. 2 below.

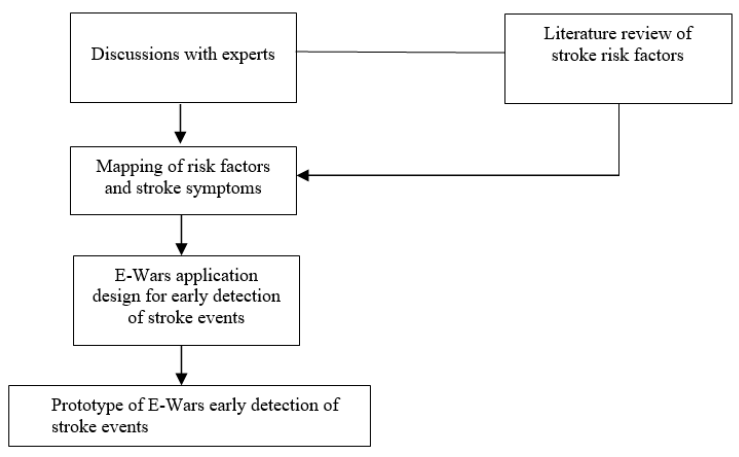

Fig. 1. Research flow

Identification of needs in question is the need for EWars prototype of stroke in patients with chronic hypertension. The needs include knowledge of the characteristics of patients with the risk of stroke and symptoms of stroke obtained from experts, in this case specialists in neurological disease. Data taken with discussions with the experts were combined with references on stroke risk factors. The references were derived from 15 sources consisting of journal articles, books and proceedings, done by searching for similarities (contrast), creating views (criticize), then comparing (synthesize) and summarizing.

Prototype development was done by mapping the risk factors and stroke symptoms in the patients, then the inference mechanism was made to allow early detection in patients with risk of stroke. The mechanism of inference was made through discussion activities with experts. The design results that have been appropriate or accepted can be used operationally. However, due to limited time research, the operational application of the prototype had not been done.

\section{RESULTS}

Literature review showed that stroke risk factors were divided into two, the modifiable and non-modifiable stroke risk factors. The modifiable stroke risk factors were hypertension, blood sugar, cholesterol, heart disease, obesity, smoking, alcohol consumption, stress, physical activity, social factors, education, and marital status (Nastiti 2012). Whereas, the non-modifiable stroke risk were age, sex, race, and family history with stroke (Magistris et al 2013).

A previous study on 137 medical records in Jember Hospital in 2016 revealed that $2.92 \%$ of stroke patients also sufferred from diabetes mellitus and $48.16 \%$ of stroke patients were elderly. Most of the stroke patients were male. In medical record, it was found that most of the stroke patients were Javanese. The analysis of the study showed that the most influential factors of stroke incidence in Jember Hospital were age, sex, race, hypertension and diabetes mellitus.

The results of the discussion with the expert can be concluded that there were 8 risk factors of stroke, ie hypertension, atrial fibrillation, smoking habits, hypercholesterol, diabetes, lack of physical activity, obesity and family history with stroke. The eight factors were then mapped into 3 , ie low risk, medium risk and high risk.

Table 1. Stroke risk factor mapping

\begin{tabular}{lccc}
\hline Risk factors & High risk & Medium risk & Low risk \\
\hline Blood pressure & $>140 / 90$ & $120-139 / 80-89$ & $<120 / 80$ \\
Atrial fibrillation & Irregular pulse rate & Pulse is not palpable & Regular pulse rate \\
Smoking habit & Smoker & Occasionally smoker & Not smoker \\
Cholesterol & $>240$ & $200-239$ & $<200$ \\
Diabetes & Yes & There is a family history & No \\
Physical activity & Onfrequent & Occasional & Frequent \\
Body weight & Overweight & Not sure & Normal \\
Family history with stroke & Yes & & No \\
\hline
\end{tabular}


It was regarded as high risk if the total score was more than or equal to 3 . It was medium risk if the score was between 4-6, and low risk if the score was 6-8. The experts also formulated the efforts to reduce the risk of stroke as follows: having regular blood pressure examination, immediately finding heart problem, stop smoking, checking cholesterol levels, checking blood sugar levels for diabetic patients, routine physical activity, and consuming low-salt diet.

\section{DISCUSSION}

Usecase diagram was used to describe the interaction between a system user (actor) and a case (usecase) that was tailored to the specified steps (scenario). Usecase describes the needs of the system from the users' point of view, focusing on computerized systems (automated processes), indicating the system process. E-wars usecase for early detection of stroke incidence is described in Fig. 2.

E-Wars usecase diagram for early detection of stroke incidence in Fig. 2 shows that there are 2 actors, developer and user. Developer has a role in stroke risk factor and stroke symptom mapping of literature review as results and discussions with experts and making inference into stroke risk criteria. The result grouping were then arranged into a list of questions for the user who will be logged into the algorithm, so the risk criteria will be generated. In order to use the system the user must register and input the data by filling out the questionnaire items presented in the application menu. After filling in the data, the user provides input on stroke risk factors and symptoms by checking the answer according to the condition of the user. Data Flow Diagram (DFD) (Figs. 3 and 4) is a graphical technique used to describe information flow and transformation of data from input to output (Mulyanto 2009).

Data Flow level 1 is depicted in Fig. 4 in which the flow of data from level 0 is more elaborated according to the existing risk factor data. Entity relationship is a model that is often used to design the concept of database applications (Malinowski 2009). The entity relationship model is based on the assumption that the real world consists of a collection of basic objects called entities and relationships between entities. Fig. 5 shows the ERD of E-Wars of stroke incidence.

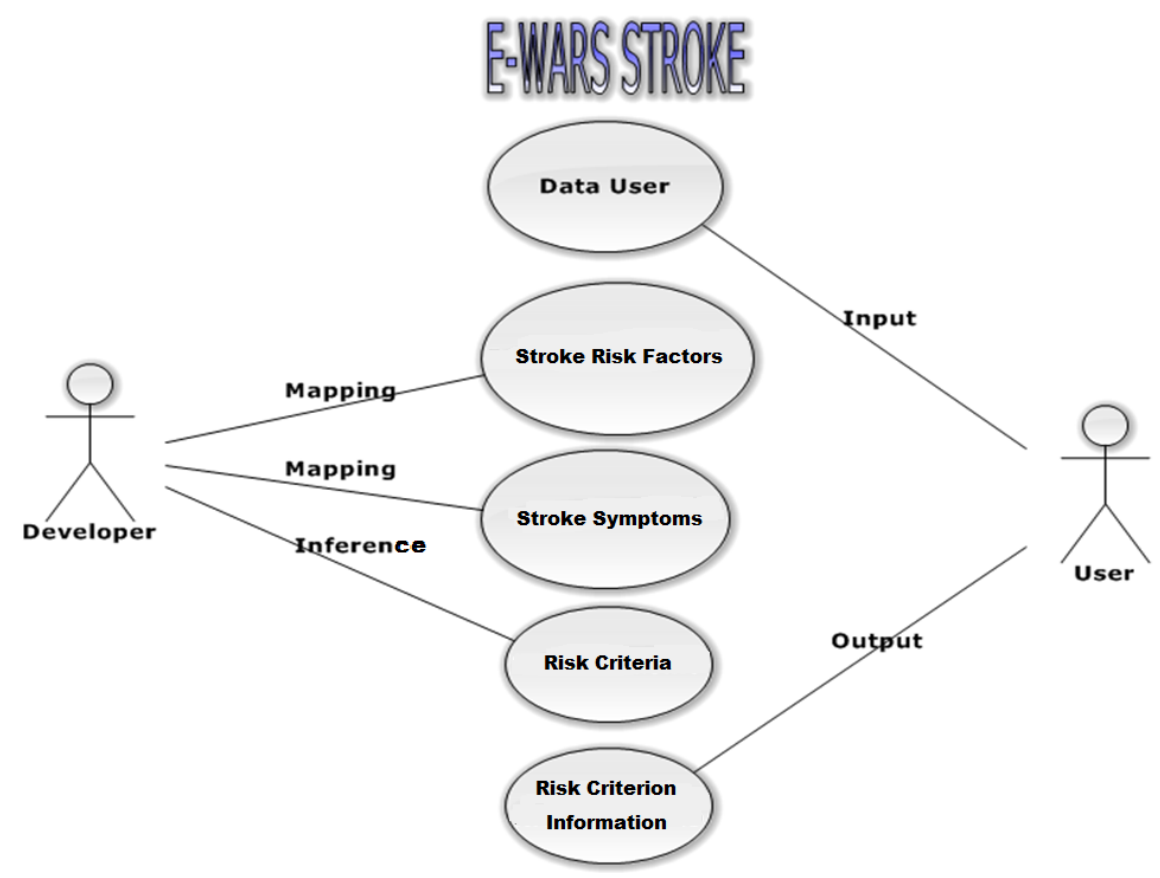

Fig. 2. Usecase E-Wars diagram for early detection of stroke occurrence. 


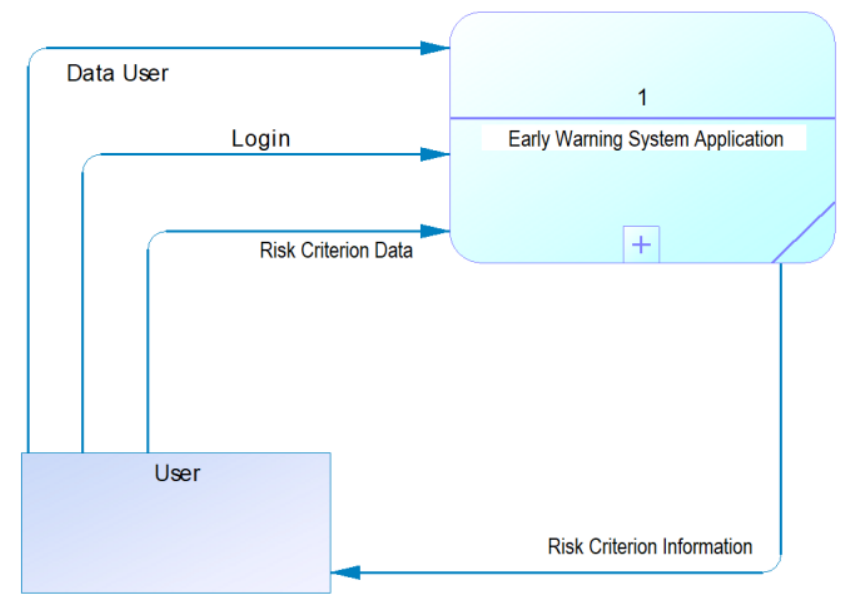

Fig. 3. DFD Level 0

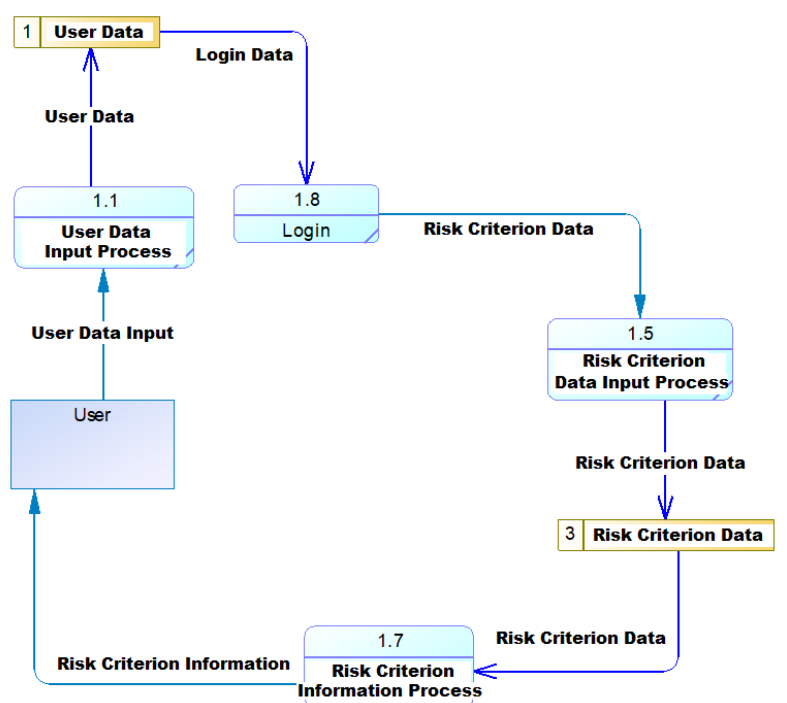

Fig. 4. DFD level 1.

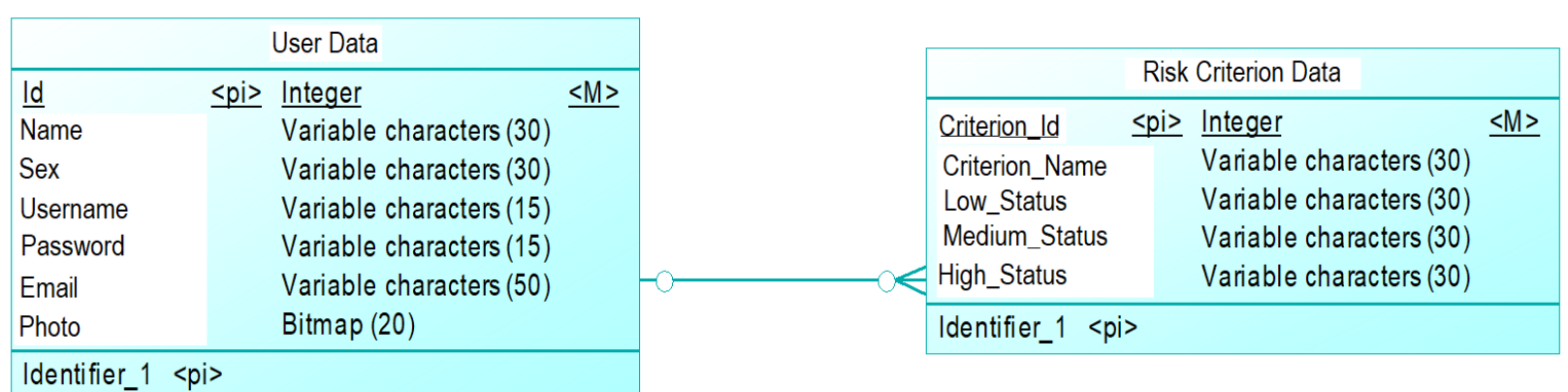

Fig. 5. Entity Relationship Diagram (ERD) of E-Wars.

Clinical decision support system (CDSS) is a computer system designed to take clinical decisions for physicians on their patients. This system aims to reduce medical errors. Factors that correlate to successful implementation of CDSS are: providing automatic alert/reminders as the part of the workflow, advising time and location where the decision is being made, providing actionable recommendations, and computerizing the entire service process. Fig. 6 shows a logical flow chart of E-Wars for early detection of stroke incidence. 


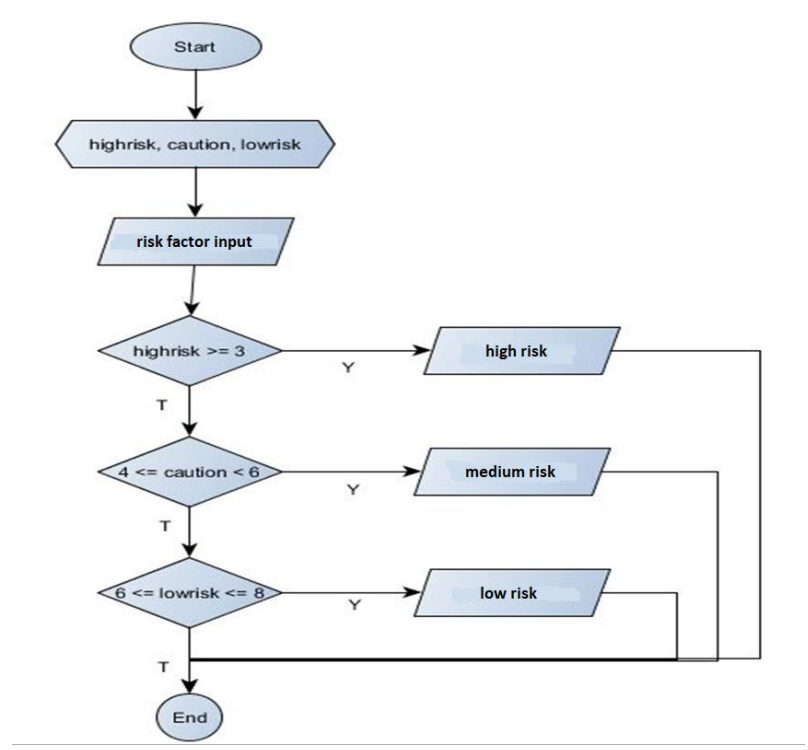

Fig. 6. Logical flow of E-Wars for stroke incidence.

\section{CONCLUSION}

E-Wars is an early detection system of stroke incidence based on the risk factors derived from literature review and the results of discussions with experts. It contains timely and significant warning information that allows risky individuals, communities and organizations to prepare and act appropriately. This prototype is expected to be operationalized into mobile applications and has a clinical impact to reduce the risk of stroke morbidity and even mortality.

\section{REFERENCES}

Fadjar E (2014). Stroke Pembunuh Nomor 3 di Dunia. Available from file:///E:/penelitian_pengabdian/PDP/ StrokePembunuhNomor3diDunia_kesehatan_ tempo. co.htm
Magistris F, Bazak S, Martin J (2013). Intracerebral hemorrhage: Pathophysiology, diagnosis and management. Available from http://www.mumj.org/Issues/ v10_2013/v10_2013.htm

Malinowski E (2009). Advanced data warehouse design from conventional to spatial and temporal applications. MJ Carey \& S. Ceri Eds.). Berlin/Heidelberg: Springer-Verlag

Mulyanto A (2009). Sistem informasi konsep \& aplikasi. Yogyakarta, Pustaka Pelajar

Nastiti D (2012). Gambaran faktor risiko kejadian stroke pada pasien rawat inap di Rumah Sakit Krakatau Medika tahun 2011. Universitas Indonesia

Putri (2015). Aplikasi smartphone untuk pantau kesehatan. Available from http://www.kompasiana. com/indihealth/xanesha-aplikasi-smartphone-untukpantau-kesehatan_54f83b6ba333112e5e8b48ab

WHO (2016). Stroke cerebrovascular accident. Available from http://www.who.int/topics/cerebrovascular accident/en/ 